\title{
Z-scheme photocatalyst systems employing Rh- and Ir-doped metal oxide materials for water splitting under visible light irradiation $\dagger$
}

\author{
Akihiko Kudo, (D) *ab Shunya Yoshino, ${ }^{a}$ Taichi Tsuchiya, ${ }^{a}$ \\ Yuhei Udagawa, ${ }^{a}$ Yukihiro Takahashi, ${ }^{a}$ Masaharu Yamaguchi, ${ }^{a}$ \\ Ikue Ogasawara, ${ }^{a}$ Hiroe Matsumoto ${ }^{a}$ and Akihide Iwase (iD ab
}

Received 27th November 2018, Accepted 24th January 2019

DOI: $10.1039 / c 8 f d 00209 f$

\begin{abstract}
Various types of Z-scheme systems for water splitting under visible light irradiation were successfully developed by employing Rh- and Ir-doped metal oxide powdered materials with relatively narrow energy gaps (EG): $\mathrm{BaTa}_{2} \mathrm{O}_{6}: \mathrm{Ir}, \mathrm{La}$ (EG: 1.9-2.0 eV), $\mathrm{NaTaO}_{3}: \mathrm{Ir}, \mathrm{La}$ (EG: 2.1-2.3 eV), $\mathrm{SrTiO}_{3}:$ Ir (EG: $1.6-1.8 \mathrm{eV}$ ), $\mathrm{NaNbO}_{3}: \mathrm{Rh}, \mathrm{Ba}\left(\mathrm{EG}: 2.5 \mathrm{eV}\right.$ ) and $\mathrm{TiO}_{2}: \mathrm{Rh}, \mathrm{Sb}$ (EG: $2.1 \mathrm{eV}$ ), with conventional $\mathrm{SrTiO}_{3}: \mathrm{Rh}$ (an $\mathrm{H}_{2}$-evolving photocatalyst) or $\mathrm{BiVO}_{4}$ (an $\mathrm{O}_{2}$-evolving photocatalyst), and suitable electron mediators. The Z-scheme systems were classified into three groups depending on the combination of $\mathrm{H}_{2}-$ and $\mathrm{O}_{2}{ }^{-}$ evolving photocatalysts and electron mediator. The Z-scheme systems combining $\mathrm{BaTa}_{2} \mathrm{O}_{6}:$ Ir, La with $\mathrm{BiVO}_{4}$, and $\mathrm{NaTaO}_{3}: \mathrm{Ir}$, La with $\mathrm{BiVO}_{4}$ were active when a $\left[\mathrm{Co}(\mathrm{bpy})_{3}\right]^{3+1}$ ${ }^{2+}$ redox couple was used rather than an $\mathrm{Fe}^{3+/ 2+}$ one. The combination of $\mathrm{SrTiO}_{3}$ :Ir with $\mathrm{SrTiO}_{3}: \mathrm{Rh}$ gave an activity when the $\left[\mathrm{Co}(\mathrm{bpy})_{3}\right]^{3+/ 2+}$ and $\mathrm{Fe}^{3+/ 2+}$ redox couple ionic mediators were used. The $\mathrm{Z}$-scheme systems combining $\mathrm{NaNbO}_{3}: \mathrm{Rh}, \mathrm{Ba}$ and $\mathrm{TiO}_{2}: \mathrm{Rh}, \mathrm{Sb}$ with $\mathrm{SrTiO}_{3}: \mathrm{Rh}$ showed activities by using the $\left[\mathrm{Co}(\mathrm{bpy})_{3}\right]^{3+/ 2+}$ and $\mathrm{Fe}^{3+/ 2+}$ redox couples and also via interparticle electron transfer by just contact with/without reduced graphene oxide (RGO). These suitable combinations can be explained based on the impurity levels of doped $\mathrm{Rh}^{3+}$ and $\mathrm{Ir}^{3+}$ toward the redox potentials of the ionic mediators for the Z-scheme systems employing ionic mediators, and $\mathrm{p}$-/n-type and onset potentials of the photocurrent in the photoelectrochemical properties of those photocatalyst materials for the Z-scheme systems working via interparticle electron transfer.
\end{abstract}

\footnotetext{
${ }^{a}$ Department of Applied Chemistry, Faculty of Science, Tokyo University of Science, 1-3 Kagurazaka, Shinjuku-ku, Tokyo 162-8601, Japan. E-mail: a-kudo@rs.kagu.tus.ac.jp

${ }^{b}$ Photocatalysis International Research Center, Research Institute for Science and Technology, Tokyo University of Science, 2641, Yamazaki, Noda-shi, Chiba-ken 278-8510, Japan

$\dagger$ Electronic supplementary information (ESI) available. See DOI: 10.1039/c8fd00209f
} 


\section{Introduction}

Artificial photosynthesis has attracted attention from the view point of solar energy conversion to storable chemical energy. Because solar water splitting is one of the representative reactions, photocatalytic water splitting has extensively been studied. ${ }^{1-7}$ Powder-based metal oxide materials are attractive for photocatalytic water splitting because the cost will be $\operatorname{low}^{8-10}$ and stability will be high compared with other materials such as chalcogenides. Although the efficiency of powder-based photocatalyst systems is behind that of systems of photovoltaic + electrolysis at the present stage, there are some advantages to powder-based photocatalyst systems.

It is crucial to demonstrate a solar water splitting system employing powderbased oxide photocatalysts. The present stage of research of artificial synthesis is along this topic. A reactor system including a gas separation system of evolved hydrogen from oxygen has been studied in addition to the development of photocatalyst materials aimed towards the practical use of solar water splitting. ${ }^{10}$ The separation system can be achieved by the use of a suitable separation membrane. Moreover, the safety issue of the co-evolved $\mathrm{H}_{2}$ and $\mathrm{O}_{2}$ has also been examined via the use of a suitable gas transportation tube. However, even if an excellent reactor system with a gas separation membrane system is established, which photocatalyst is employed for it is still a key issue as high efficient photocatalysts for real solar water splitting into $\mathrm{H}_{2}$ and $\mathrm{O}_{2}$ without any sacrificial electron donors and acceptors have not yet been developed. It is essential to develop an efficient photocatalyst for demonstrating a solar water splitting system taking gas separation and safety issues into account.

High efficiency of a photocatalyst can be brought about by a high quantum yield and a response to light with a long wavelength. From this viewpoint, it is vital to develop photocatalysts that can utilize up to $600-700 \mathrm{~nm}$ of the solar spectrum. Although the use of noble metals might prevent the photocatalyst materials from practical use, the usage would be allowed if the amount is small and the materials can be recycled.

There are single particulate and Z-scheme systems in powder-based photocatalysts. $^{2,11} \mathrm{Z}$-scheme photocatalyst systems have the advantage that photocatalysts active for either $\mathrm{H}_{2}$ or $\mathrm{O}_{2}$ evolution can be employed. This means that a Z-scheme system can be constructed with various combinations of $\mathrm{H}_{2^{-}}$and $\mathrm{O}_{2}$-evolving photocatalysts. ${ }^{12-15} \mathrm{SrTiO}_{3}$ : $\mathrm{Rh}$ (an $\mathrm{H}_{2}$-evolving photocatalyst) and $\mathrm{BiVO}_{4}$ (an $\mathrm{O}_{2}{ }^{-}$ evolving photocatalyst) are representative metal oxide materials for the Z-scheme system. ${ }^{1,2,16}$ It should be stressed that photocatalyst sheets prepared by a particle transfer method using $\mathrm{SrTiO}_{3}: \mathrm{Rh}, \mathrm{La}$ and $\mathrm{BiVO}_{4}:$ Mo powders demonstrate a quantum efficiency of $30 \%$ at $420 \mathrm{~nm}$ and a solar to hydrogen energy conversion efficiency of $1 \% .{ }^{17-19}$ This result suggests that the Z-scheme system is a promising photocatalyst system for practical solar water splitting. $\mathrm{H}_{2}$ evolution separated from $\mathrm{O}_{2}$ evolution is possible in the $\mathrm{Z}$-scheme system if a suitable reactor is designed. ${ }^{8}$ However, this photocatalyst sheet consisting of the $\mathrm{SrTiO}_{3}: \mathrm{Rh}, \mathrm{La}$ and $\mathrm{BiVO}_{4}: \mathrm{Mo}$ powders responds up to $520 \mathrm{~nm}$ because the energy gap (EG) of $\mathrm{SrTiO}_{3}: \mathrm{Rh}, \mathrm{La}$ and the band gap (BG) of $\mathrm{BiVO}_{4}: \mathrm{Mo}$ are $2.3 \mathrm{eV}$ and $2.4 \mathrm{eV}$, respectively. So, it is a key issue to develop Z-scheme photocatalyst systems consisting of metal oxide photocatalysts with a response at longer wavelengths than $520 \mathrm{~nm}$. 
Transition metal doping is one strategy to make wide band gap photocatalysts responsive to visible light. ${ }^{1,2} \mathrm{Rh}$ and $\mathrm{Ir}$ are effective dopants in this strategy. We have reported that $\mathrm{SrTiO}_{3}: \mathrm{Rh}(\mathrm{EG}: 2.3 \mathrm{eV}){ }^{20} \mathrm{SrTiO}_{3}: \mathrm{Rh}, \mathrm{Sb}(\mathrm{EG}: 2.2-2.4 \mathrm{eV}),{ }^{21}$ $\mathrm{SrTiO}_{3}$ :Ir (EG: 1.6-1.8 eV), ${ }^{20,22} \mathrm{BaTa}_{2} \mathrm{O}_{6}: \mathrm{Ir}, \mathrm{La}$ (EG: $\left.1.9-2.0 \mathrm{eV}\right)^{23}$ and $\mathrm{NaTaO}_{3}: \mathrm{Ir}, \mathrm{La}$ (EG: $2.1-2.3 \mathrm{eV})^{24}$ are active for sacrificial $\mathrm{H}_{2}$ evolution in the presence of electron donors such as methanol, while $\mathrm{SrTiO}_{3}: \mathrm{Rh}, \mathrm{Sb},{ }^{21} \mathrm{SrTiO}_{3}: \mathrm{Ir}^{20}$ and $\mathrm{TiO}_{2}: \mathrm{Rh}, \mathrm{Sb}$ (EG: $2.1 \mathrm{eV})^{25}$ are active for sacrificial $\mathrm{O}_{2}$ evolution in the presence of electron acceptors such as $\mathrm{Ag}^{+}$. In these photocatalyst materials, the visible light responses are due to electronic transition from the impurity levels formed by the dopants to the conduction bands of the host materials. These energy and band gaps are close to, or narrower than, those of $\mathrm{SrTiO}_{3}$ : Rh (EG: $\left.2.3 \mathrm{eV}\right)^{20}$ and $\mathrm{BiVO}_{4}$ (BG: $2.4 \mathrm{eV}$ ). ${ }^{26,27} \mathrm{So}$, it is attractive to utilize these Rh- and Ir-doped metal oxide photocatalysts for the construction of Z-scheme systems.

There are several types of Z-scheme system employing different electron mediators such as $\mathrm{Fe}^{3+/ 2+}$ and $\left[\mathrm{Co}(\mathrm{bpy})_{3}\right]^{3+/ 2+}$ redox couples, ${ }^{16,28,29}$ and reduced graphene oxide (RGO) ${ }^{30-32}$ as shown in Fig. 1(a) and (b). Moreover, some Z-scheme systems work even without electron mediators, as shown in Fig. 1(c). ${ }^{33,34}$ In this case, electron transfer proceeds through an interface contacted between the particles of the $\mathrm{H}_{2}$ - and $\mathrm{O}_{2}$-evolving photocatalysts. So, it is important to examine the electron mediator in the $\mathrm{Z}$-scheme system.

In the present paper, sacrificial $\mathrm{H}_{2}$ and $\mathrm{O}_{2}$ evolutions over Rh- and Ir-doped metal oxide photocatalysts under visible light irradiation were examined first to see the relationship between the photocatalytic properties and their band structures. Then, these $\mathrm{H}_{2}$ - and $\mathrm{O}_{2}$-evolving photocatalysts were employed for various types of Z-scheme system for water splitting into $\mathrm{H}_{2}$ and $\mathrm{O}_{2}$ in stoichiometric amounts under visible light irradiation, without any sacrificial reagents. The photocatalytic performances for the sacrificial $\mathrm{H}_{2}$ and $\mathrm{O}_{2}$ evolutions and the $\mathrm{Z}$ schematic water splitting were discussed based on the band structures and

(a) Ionic electron mediator

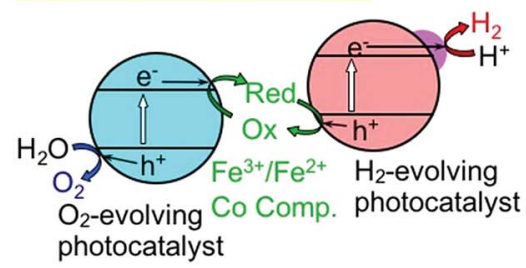

(c) No electron mediator (Contact)

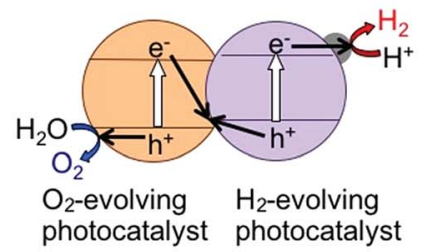

(b) Solid electron mediator (RGO)

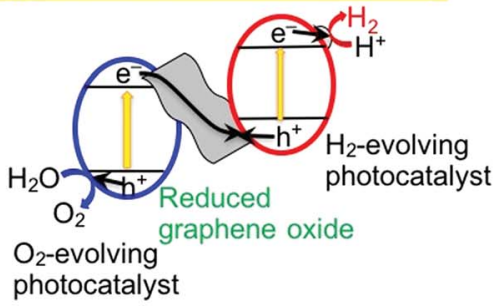

(d) Photoelectrochemical cell

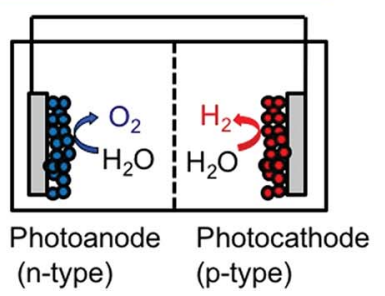

Fig. 1 Various types of powder material-based Z-scheme systems for water splitting. 
photoelectrochemical properties of the photocatalyst materials such as $\mathrm{p}$-/n-types and the onset potentials of photocurrents.

\section{Experimental}

\section{Preparation of Rh- or Ir-doped metal oxide photocatalysts}

$\mathrm{SrTiO}_{3}: \mathrm{Rh}(1 \%),{ }^{29} \mathrm{SrTiO}_{3}: \operatorname{Ir}(0.2 \%),{ }^{22} \mathrm{TiO}_{2}: \mathrm{Rh}(x \%), \mathrm{Sb}(2 x \%)(x=0.5$ or 1.3$),{ }^{25}$ $\mathrm{NaTaO}_{3}: \operatorname{Ir}(1 \%), \mathrm{La}(2 \%),{ }^{24} \mathrm{BaTa}_{2} \mathrm{O}_{6}: \operatorname{Ir}(1 \%), \mathrm{La}(2 \%)^{23}$ and $\mathrm{BiVO}_{4}{ }^{26,27}$ were prepared by a solid-state reaction, a borate-flux method, and a liquid-solid reaction according to previous reports. In addition to them, $\mathrm{NaNbO}_{3}: \operatorname{Rh}(x \%), \mathrm{Ba}(y \%)(x$, $y)=(1.2,1.44)$ or $(1.0,2.0)$ was newly prepared by a solid-state reaction. The starting materials, $\mathrm{Na}_{2} \mathrm{CO}_{3}$ (Kanto Chemical; 99.5 or 99.8\%), $\mathrm{Nb}_{2} \mathrm{O}_{5}$ (Kanto Chemical; 99.99\% or Kojundo Chemical; 99.99\%), $\mathrm{Rh}_{2} \mathrm{O}_{3}$ (Wako Chemical; 98\%), and $\mathrm{BaCO}_{3}$ (Kanto Chemical; 99\%), were mixed at a molar ratio of $\mathrm{Na} / \mathrm{Nb} / \mathrm{Rh} / \mathrm{Ba}=$ $1.05-1.05 y: 1-x: x: y$. An excess of sodium was added in the starting materials to compensate for volatilization. The starting materials mixture was calcined at $1173 \mathrm{~K}$ for $1 \mathrm{~h}$, and then $1423-1473 \mathrm{~K}$ for $10 \mathrm{~h}$ once or twice. The excess sodium was washed out with water after the calcination. The obtained powders had nonspecific shapes with aggregations, judging from the SEM images (Jeol; JSM6700F) (Fig. S1†). The obtained samples were identified using X-ray diffraction (Rigaku; MiniFlex, $\mathrm{Cu} \mathrm{K} \alpha$ ). Diffuse reflectance spectra were obtained by a UV-visNIR spectrometer (JASCO, V-570) equipped with an integrator sphere and were converted to absorbance measurements via the Kubelka-Munk method.

\section{Preparation of an RGO-metal oxide composite}

An RGO-incorporated $\mathrm{O}_{2}$-evolving photocatalyst was prepared by photocatalytic reduction of graphene oxide (GO) on the photocatalyst according to previous reports. ${ }^{30-32}$ GO prepared by the Hummers' method ${ }^{35}$ and the $\mathrm{O}_{2}$-evolving photocatalyst were dispersed in an aqueous methanol (Kanto Chemical; 99.8\%) solution (50 vol\%). The suspension was irradiated with visible light from a $300 \mathrm{~W}$ Xe lamp (PerkinElmer; CERMAX PE300BF) with a long pass filter (HOYA; L42) under a $\mathrm{N}_{2}$ atmosphere with a pressure of $1 \mathrm{~atm}$ to obtain the RGO-photocatalyst composite. The methanol was carefully removed by washing with water. The RGO-photocatalyst composite was collected by filtration and was dried at room temperature in air.

\section{Sacrificial $\mathrm{H}_{2}$ and $\mathrm{O}_{2}$ evolutions (half reactions of water splitting)}

$\mathrm{H}_{2}$ and $\mathrm{O}_{2}$ evolutions from aqueous solutions containing the sacrificial reagents $\mathrm{CH}_{3} \mathrm{OH}$ (Kanto Chemical; 99.8\%) and $\mathrm{AgNO}_{3}$ (Kojima Chemical; 99.9\% or Toyo Chemical; 99.9\%) that were half reactions of water splitting were examined using a top-irradiation reaction cell with a Pyrex window and a $300 \mathrm{~W}$ Xe lamp (PerkinElmer; CERMAX PE300BF). $\mathrm{NaTaO}_{3}: \mathrm{Ir}, \mathrm{La}, \mathrm{BaTa}_{2} \mathrm{O}_{6}: \mathrm{Ir}, \mathrm{La}, \mathrm{NaNbO}_{3}: \mathrm{Rh}, \mathrm{Ba}$, and $\mathrm{TiO}_{2}: \mathrm{Rh}, \mathrm{Sb}$ were used as prepared, whereas $\mathrm{SrTiO}_{3}$ :Ir without a cocatalyst was reduced under $1 \mathrm{~atm}$ of $\mathrm{H}_{2}$ at $473 \mathrm{~K}$ for $2 \mathrm{~h}$ as a pretreatment for sacrificial $\mathrm{O}_{2}$ evolution. The photocatalyst powders $(0.1-0.3 \mathrm{~g})$ were suspended in aqueous solutions (120-150 mL) and irradiated with visible light. For the $\mathrm{H}_{2}$ evolution, $\mathrm{Pt}$ (0.3 wt\%) cocatalyst, working as an $\mathrm{H}_{2}$ evolution site, was loaded on photocatalysts by photodeposition from an aqueous methanol solution containing 
$\mathrm{H}_{2} \mathrm{PtCl}_{6}$ (Tanaka Kikinzoku; $37.55 \%$ as $\mathrm{Pt}$ ). The wavelength of the irradiation light was controlled to visible light using long-pass filters (HOYA; L42 and Y44). The amounts of evolved $\mathrm{H}_{2}$ and $\mathrm{O}_{2}$ were determined using an online gas chromatograph (Shimadzu; GC-8A, MS-5A column, TCD, Ar carrier).

\section{Z-schematic water splitting}

Z-schematic water splitting was conducted using a gas-closed system with a topirradiation cell with a Pyrex window. $\mathrm{H}_{2}$-evolving photocatalyst and $\mathrm{O}_{2}$-evolving photocatalyst powders ( 0.05 or $0.1 \mathrm{~g}$, respectively) were suspended in $120 \mathrm{~mL}$ of water. For the interparticle Z-scheme systems without an electron mediator and with an RGO solid-state electron mediator, water not containing any ionic mediators was used. For the Z-scheme system with ionic mediator, an aqueous solution containing $\left[\mathrm{Co}(\mathrm{bpy})_{3}\right] \mathrm{SO}_{4}$ or $\mathrm{FeCl}_{3}$ as a mediator was used. The $\mathrm{pH}$ was adjusted with $\mathrm{H}_{2} \mathrm{SO}_{4}$ in each of the Z-scheme systems with and without electron mediator, if necessary. $\mathrm{Ru}(0.7 \mathrm{wt} \%)$ cocatalyst, functioning as an $\mathrm{H}_{2}$ evolution site, was loaded on $\mathrm{SrTiO}_{3}: \mathrm{Rh}$ (an $\mathrm{H}_{2}$-evolving photocatalyst) by photodeposition from an aqueous methanol solution containing $\mathrm{RuCl}_{3} \cdot n \mathrm{H}_{2} \mathrm{O}$ (Tanaka Kikinzoku; $36 \%$ as $\mathrm{Ru}$ in $\left.\mathrm{RuCl}_{3} \cdot n \mathrm{H}_{2} \mathrm{O}\right)$. Pt (0.3-1 wt\%) was loaded on the $\mathrm{NaTaO}_{3}: \mathrm{Ir}, \mathrm{La}$ and $\mathrm{BaTa}_{2} \mathrm{O}_{6}: \mathrm{Ir}, \mathrm{La}\left(\mathrm{H}_{2}\right.$-evolving photocatalysts), and $\mathrm{SrTiO}_{3}$ :Ir (an $\mathrm{O}_{2}$-evolving photocatalyst) by an impregnation method. The photocatalyst powders and an aqueous $\mathrm{H}_{2} \mathrm{PtCl}_{6}$ solution were placed in a porcelain crucible and dried on a hot plate. The $\mathrm{H}_{2} \mathrm{PtCl}_{6}$-impregnated $\mathrm{NaTaO}_{3}$ :Ir,La and $\mathrm{BaTa}_{2} \mathrm{O}_{6}$ :Ir,La powders were calcined at $673 \mathrm{~K}$ for $2 \mathrm{~h}$ in air, whereas the $\mathrm{SrTiO}_{3}$ :Ir was not. The Pt-loaded $\mathrm{NaTaO}_{3}: \mathrm{Ir}$,La and Pt-loaded $\mathrm{BaTa}_{2} \mathrm{O}_{6}:$ Ir,La were subsequently reduced at $673 \mathrm{~K}$ for $1 \mathrm{~h}$ under $1 \mathrm{~atm}$ of $\mathrm{H}_{2}$ as a pretreatment, while Pt-loaded $\mathrm{SrTiO}_{3}$ :Ir was reduced at $573 \mathrm{~K}$ for $1 \mathrm{~h}$. The light source and GC setup were the same as those for the sacrificial $\mathrm{H}_{2}$ and $\mathrm{O}_{2}$ evolutions.

\section{Photoelectrochemical measurements}

A squeegee method was used to prepare the $\mathrm{SrTiO}_{3}: \mathrm{Rh}(1 \%)$ photoelectrode and a drop-casting method was used for the $\mathrm{NaTaO}_{3}: \operatorname{Ir}(1 \%), \mathrm{La}(2 \%)$ and $\mathrm{BaTa}_{2} \mathrm{O}_{6}$ :$\operatorname{Ir}(1 \%), \mathrm{La}(2 \%)$ with and without $\mathrm{H}_{2}$-reduction; $\mathrm{SrTiO}_{3}: \operatorname{Ir}(0.2 \%)$ with $\mathrm{H}_{2}$-reduction; $\mathrm{NaNbO}_{3}: \mathrm{Rh}(1 \%), \mathrm{Ba}(2 \%)$ and $\mathrm{TiO}_{2}: \mathrm{Rh}(0.5 \%), \mathrm{Sb}(1 \%)$ without $\mathrm{H}_{2}$-reduction, and $\mathrm{BiVO}_{4}$ photoelectrodes using powdered photocatalyst materials. For the $\mathrm{SrTiO}_{3}$ :$\mathrm{Rh}(1 \%)$ photoelectrode, a paste consisting of $20 \mathrm{mg}$ of $\mathrm{SrTiO}_{3}: \mathrm{Rh}(1 \%)$ photocatalyst powder, $20 \mu \mathrm{L}$ of acetylacetone (Kanto Chemical; 99.5\%) and $40 \mu \mathrm{L}$ of distilled water was coated on an indium tin oxide transparent electrode (ITO). ${ }^{36}$ For the other photoelectrodes, the photocatalyst powders were dispersed in ethanol (1-2 $\mathrm{mg} \mathrm{mL}^{-1}$ ) by sonication. The suspensions were drop-cast onto a fluorine-doped tin oxide transparent electrode (FTO) to obtain 1-2 $\mathrm{mg} \mathrm{cm}^{-2}$ of photocatalyst on the FTO. The $\mathrm{H}_{2}$-reduced $\mathrm{SrTiO}_{3}$ :Ir-loaded FTO substrate was not calcined, whereas the other photocatalyst-loaded ITO and FTO substrates were calcined at 573-673 $\mathrm{K}$ for $2 \mathrm{~h}$ in air. The photoelectrochemical properties were evaluated with a three-electrode system consisting of working, $\mathrm{Ag} / \mathrm{AgCl}$ reference, and Pt counter electrodes with a potentiostat (Hokuto Denko; HZ-series or HSV110) using a conventional $\mathrm{H}$-type cell with a Nafion membrane. The electrolyte was $0.1 \mathrm{~mol} \mathrm{~L}^{-1} \mathrm{~K}_{2} \mathrm{SO}_{4} .0 .025 \mathrm{~mol} \mathrm{~L}^{-1} \mathrm{KH}_{2} \mathrm{PO}_{4}+0.025 \mathrm{~mol} \mathrm{~L}^{-1} \mathrm{Na}_{2} \mathrm{HPO}_{4} \mathrm{pH}$ buffer 
was added, if necessary. A $300 \mathrm{~W}$ Xe lamp (PerkinElmer; CERMAX PE300BF) with a long-pass filter (HOYA; L42) was employed as a light source.

\section{Results}

\section{Photocatalytic activities for sacrificial $\mathrm{H}_{2}$ and $\mathrm{O}_{2}$ evolutions over Rh- and Ir- doped metal oxide materials and their band structures}

Sacrificial $\mathrm{H}_{2}$ and $\mathrm{O}_{2}$ evolutions of half reactions were carried out as test reactions of water splitting over Rh- and Ir-doped metal oxide photocatalysts using a sacrificial electron donor and acceptor to see the ability for photocatalytic $\mathrm{H}_{2}$ or $\mathrm{O}_{2}$ evolution, as shown in Table 1, prior to conducting water splitting.

The energy gaps were determined from the diffuse reflectance spectra and wavelength dependence of the photocatalytic activities as shown in Fig. 2 and 3. In general, trivalent and tetravalent $\mathrm{Rh}$ and $\mathrm{Ir}$ species are doped at the $\mathrm{Ti}^{4+}, \mathrm{Nb}^{5+}$ and $\mathrm{Ta}^{5+}$ sites in metal oxide materials..$^{20-25,37,38}$ Among the species, $\mathrm{Rh}^{3+}$ and $\mathrm{Ir}^{3+}$ contribute to the visible light response for metal oxide photocatalysts. ${ }^{20,24,37,38} \mathrm{Sb}^{5+}$ was codoped with $\mathrm{Rh}^{3+}$ at the $\mathrm{Ti}^{4+}$ and $\mathrm{Nb}^{5+}$ sites for charge compensation to enhance the formation of $\mathrm{Rh}^{3+}$ and $\mathrm{Ir}^{3+}$ and suppress the formation of $\mathrm{Rh}^{4+}$ and $\mathrm{Ir}^{4+}$ as efficient recombination centers between photogenerated electrons and holes, while $\mathrm{Ba}^{2+}$ and $\mathrm{La}^{3+}$ were replaced at the alkali and alkaline earth metal sites for the same purpose. $\mathrm{SrTiO}_{3}$ :Ir was reduced with $\mathrm{H}_{2}$ at $473 \mathrm{~K}$ to form the dopant $\mathrm{Ir}^{3+}$.

In the case of the Ir-doped photocatalysts, $\mathrm{SrTiO}_{3}: \mathrm{Ir}$ was active for both the sacrificial $\mathrm{H}_{2}$ and $\mathrm{O}_{2}$ evolutions, ${ }^{20,22}$ whereas $\mathrm{BaTa}_{2} \mathrm{O}_{6}$ : $\mathrm{Ir}$,La and $\mathrm{NaTaO}_{3}: \mathrm{Ir}$,La were active only for the sacrificial $\mathrm{H}_{2}$ evolution. ${ }^{23,24} \mathrm{BaTa}_{2} \mathrm{O}_{6}$ :Ir,La and $\mathrm{NaTaO}_{3}$ :Ir,La were not active for sacrificial $\mathrm{O}_{2}$ evolution even if they were reduced with $\mathrm{H}_{2}$ at 673 $\mathrm{K}$, as $\mathrm{SrTiO}_{3}$ :Ir was, to reduce the $\mathrm{Ir}^{4+}$ species. The Rh-doped photocatalysts

Table 1 Sacrificial $\mathrm{H}_{2}$ and $\mathrm{O}_{2}$ evolutions under visible light irradiation over $\mathrm{Rh}$ - or Ir-doped metal oxide photocatalysts ${ }^{a}$

\begin{tabular}{|c|c|c|c|c|c|}
\hline \multirow[b]{2}{*}{ Photocatalyst } & \multirow[b]{2}{*}{ Energy gap/eV } & \multirow{2}{*}{$\begin{array}{l}\text { Incident } \\
\text { light/nm }\end{array}$} & \multicolumn{2}{|c|}{$\begin{array}{l}\text { Activity/ } \\
\mu \mathrm{mol} \mathrm{h}^{-1}\end{array}$} & \multirow[b]{2}{*}{ Ref. } \\
\hline & & & $\mathrm{H}_{2}{ }^{b}$ & $\mathrm{O}_{2}{ }^{c}$ & \\
\hline $\mathrm{Pt} / \mathrm{NaTaO}_{3}: \operatorname{Ir}(1 \%), \mathrm{La}(2 \%)$ & $2.1-2.3$ & $\lambda>420$ & 3.2 & - & 24 \\
\hline $\mathrm{NaTaO}_{3}: \operatorname{Ir}(1 \%), \mathrm{La}(2 \%)$ & $2.1-2.3$ & $\lambda>420$ & - & 0 & 24 \\
\hline $\mathrm{Pt} / \mathrm{BaTa}_{2} \mathrm{O}_{6}: \operatorname{Ir}(1 \%), \mathrm{La}(2 \%)$ & $1.9-2.0$ & $\lambda>420$ & 4.6 & - & 23 \\
\hline $\mathrm{BaTa}_{2} \mathrm{O}_{6}: \operatorname{Ir}(1 \%), \mathrm{La}(2 \%)$ & $1.9-2.0$ & $\lambda>420$ & - & 0 & 23 \\
\hline $\mathrm{Pt} / \mathrm{SrTiO}_{3}: \operatorname{Ir}(0.2 \%)$ & $1.6-1.8$ & $\lambda>440$ & 8.6 & - & 20 \\
\hline $\mathrm{SrTiO}_{3}: \operatorname{Ir}(0.2 \%)^{d}$ & $1.6-1.8$ & $\lambda>420$ & - & 4.3 & 20 \\
\hline $\mathrm{Pt} / \mathrm{NaNbO}_{3}: \mathrm{Rh}(1 \%), \mathrm{Ba}(2 \%)$ & 2.5 & $\lambda>420$ & 0.2 & - & This work \\
\hline $\mathrm{NaNbO}_{3}: \mathrm{Rh}(1 \%), \mathrm{Ba}(2 \%)$ & 2.5 & $\lambda>420$ & - & 5.3 & This work \\
\hline $\mathrm{Pt} / \mathrm{TiO}_{2}: \mathrm{Rh}(0.5 \%), \mathrm{Sb}(1 \%)$ & 2.1 & $\lambda>440$ & 0 & - & This work \\
\hline $\mathrm{TiO}_{2}: \mathrm{Rh}(0.5 \%), \mathrm{Sb}(1 \%)$ & 2.1 & $\lambda>440$ & - & 7.5 & 25 \\
\hline
\end{tabular}




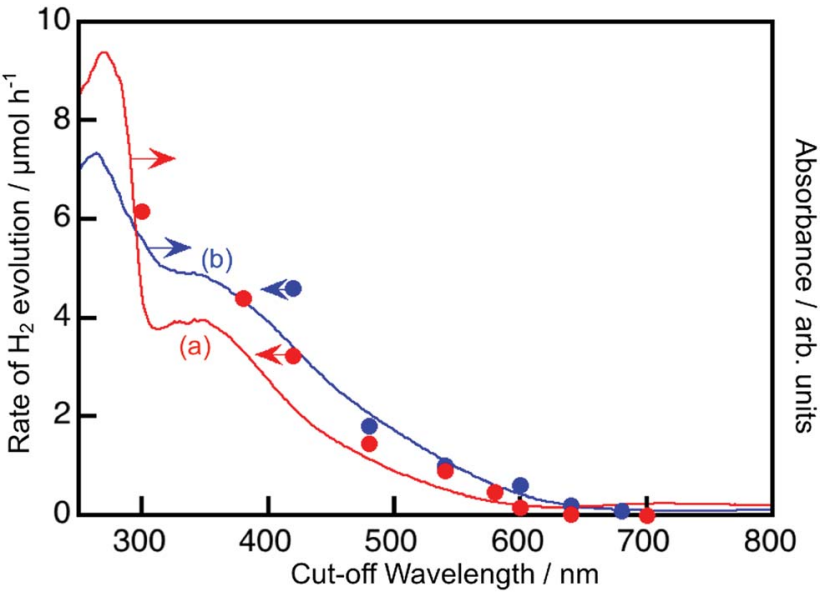

Fig. 2 The wavelength dependence of $\mathrm{H}_{2}$ evolution from a 10 vol\% aqueous methanol solution (closed circles) and diffuse reflectance spectra (solid line) of (a) $\mathrm{NaTaO}_{3}$ :$\operatorname{Ir}(1 \%), \mathrm{La}(2 \%)$ and (b) $\mathrm{BaTa}_{2} \mathrm{O}_{6}: \operatorname{Ir}(1 \%), \mathrm{La}(2 \%)$. Photocatalyst: $0.1 \mathrm{~g}$, cocatalyst: Pt (photodeposition) for $\mathrm{H}_{2}$ evolution, reactant solution: $120 \mathrm{~mL}$, light source: $300 \mathrm{~W}$ Xe lamp with long-pass filters, and reaction cell: top-irradiation cell with a Pyrex window. Samples of diffuse reflectance spectra were reduced at $473 \mathrm{~K}$.

$\mathrm{TiO}_{2}: \mathrm{Rh}, \mathrm{Sb}^{25}$ and $\mathrm{NaNbO}_{3}: \mathrm{Rh}, \mathrm{Ba}$ were active for sacrificial $\mathrm{O}_{2}$ evolution using $\mathrm{Ag}^{+}$ as an electron acceptor. $\mathrm{NaNbO}_{3}: \mathrm{Rh}, \mathrm{Ba}$ showed very low activity for the sacrificial $\mathrm{H}_{2}$ evolution. These properties will be discussed based on the band structure in the Discussion section. These results of the sacrificial $\mathrm{H}_{2}$ and $\mathrm{O}_{2}$ evolutions suggest that $\mathrm{NaTaO}_{3}: \mathrm{Ir}$, La and $\mathrm{BaTa}_{2} \mathrm{O}_{6}$ :Ir, La can be used as $\mathrm{H}_{2}$-evolving

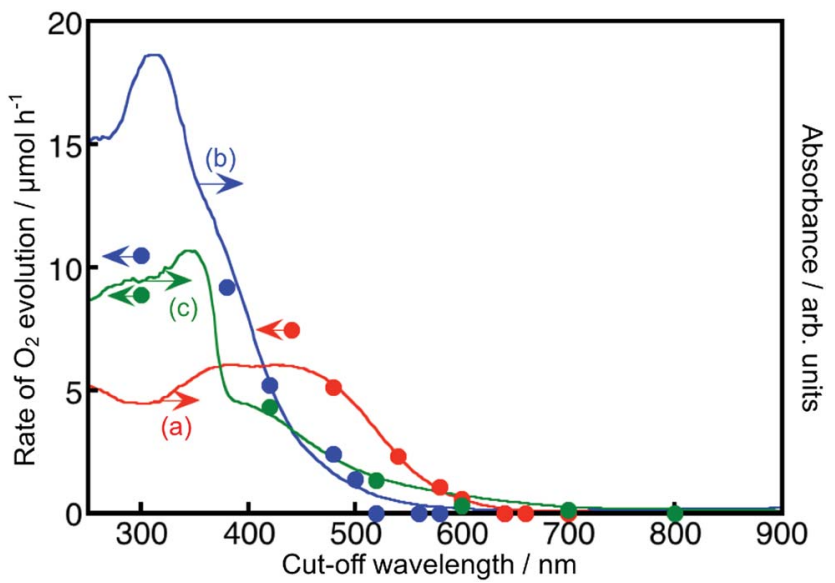

Fig. 3 The wavelength dependence of $\mathrm{O}_{2}$ evolution from a $0.05 \mathrm{~mol} \mathrm{~L}^{-1}$ aqueous silver nitrate solution (closed circles) and diffuse reflectance spectra (solid line) of (a) $\mathrm{TiO}_{2}$ :$\mathrm{Rh}(1.3 \%), \mathrm{Sb}(2.6 \%)$, (b) $\mathrm{NaNbO}_{3}: \mathrm{Rh}(1.2 \%), \mathrm{Ba}(1.44 \%)$ and (c) $\mathrm{SrTiO}_{3}: \operatorname{Ir}(0.2 \%)$ with $\mathrm{H}_{2}$ reduction at $473 \mathrm{~K}$. Photocatalyst: $0.1-0.3 \mathrm{~g}$, reactant solution: $150 \mathrm{~mL}$, light source: $300 \mathrm{~W}$ Xe lamp with long-pass filters, and reaction cell: top-irradiation cell with a Pyrex window. 
photocatalysts for the construction of Z-scheme systems, while $\mathrm{SrTiO}_{3}: \mathrm{Ir}$, $\mathrm{NaNbO}_{3}: \mathrm{Rh}, \mathrm{Ba}$ and $\mathrm{TiO}_{2}: \mathrm{Rh}, \mathrm{Sb}$ are expected to be employed as $\mathrm{O}_{2}$-evolving photocatalysts.

Fig. 2 and 3 show the diffuse reflectance spectra and wavelength dependence of the photocatalytic $\mathrm{H}_{2}$ and $\mathrm{O}_{2}$ evolutions of the Rh- and Ir-doped metal oxide photocatalysts in the presence of sacrificial reagents. The wavelengths were controlled with long-pass filters. It is vital to see the wavelength dependency of the photocatalytic activity because it is not guaranteed that photocatalysts with visible light absorption bands always give activities under visible light irradiation. The onsets of the wavelength dependence agreed with those of the diffuse reflection spectra. The onset wavelengths for the $\mathrm{H}_{2}$ evolutions were 640 and $600 \mathrm{~nm}$ for $\mathrm{BaTa}_{2} \mathrm{O}_{6}: \mathrm{Ir}, \mathrm{La}$ and $\mathrm{NaTaO}_{3}: \mathrm{Ir}, \mathrm{La}$, respectively. These onset wavelengths were longer than the $540 \mathrm{~nm}$ of $\mathrm{SrTiO}_{3}: \mathrm{Rh}$ (a conventional $\mathrm{H}_{2}$-evolving photocatalyst). The onset wavelengths for $\mathrm{O}_{2}$ evolution were 600, 500 and $700 \mathrm{~nm}$ for $\mathrm{TiO}_{2}: \mathrm{Rh}, \mathrm{Sb}$, $\mathrm{NaNbO}_{3}: \mathrm{Rh}, \mathrm{Ba}$ and $\mathrm{SrTiO}_{3}: \mathrm{Ir}$, respectively. It is noteworthy that $\mathrm{TiO}_{2}: \mathrm{Rh}, \mathrm{Sb}$ and $\mathrm{SrTiO}_{3}: \mathrm{Ir}$ responded at longer wavelengths than the $\mathrm{BiVO}_{4}(\mathrm{BG}: 2.4 \mathrm{eV})(\mathrm{a}$ conventional $\mathrm{O}_{2}$-evolving photocatalyst).

Fig. 4 shows the band structures of the Rh- and Ir-doped metal oxide photocatalysts. The impurity levels of $\mathrm{Rh}^{3+}$ and $\mathrm{Ir}^{3+}$ were estimated from the energy gaps determined by diffuse reflection spectra supposing that the valence band consisting of $\mathrm{O} 2 \mathrm{p}$ located at $+3 \mathrm{~V} v s$. NHE at a pH of $0 .^{39}$ The absorption bands in the visible light region shown in Fig. 2 and 3 are due to electronic transition from the impurity levels consisting of $\mathrm{Rh}^{3+}$ and $\mathrm{Ir}^{3+}$ to the conduction bands of the host materials. The impurity levels formed with electron-filled orbitals of $\mathrm{Ir}^{3+}$ were around 1.0-1.2 $\mathrm{V}$ for $\mathrm{NaTaO}_{3}$ and $\mathrm{BaTa}_{2} \mathrm{O}_{6}$, while $\mathrm{Ir}^{3+}$ in $\mathrm{SrTiO}_{3}$ formed an impurity level around 1.4-1.6 $\mathrm{V}$ that was deeper than those in the cases of the tantalates. The energy levels formed with electron-filled orbitals of $\mathrm{Rh}^{3+}$ located around 2.0-2.1 V that were similar to those of $\mathrm{SrTiO}_{3}: \mathrm{Rh}$ and $\mathrm{SrTiO}_{3}: \mathrm{Rh}, \mathrm{Sb}{ }^{20,21}$ The reason $\mathrm{Rh}^{3+}$ forms a deeper impurity level than $\mathrm{Ir}^{3+}$ is due to $\mathrm{Ir}^{4+}$ being more stable than $\mathrm{Rh}^{4+}$ in metal oxides. Therefore, electronic transition from the $\mathrm{Ir}^{3+}$ impurity level to a conduction band is easier than that from $\mathrm{Rh}^{3+}$, resulting in the formation of the shallow impurity level by $\mathrm{Ir}^{3+}$.

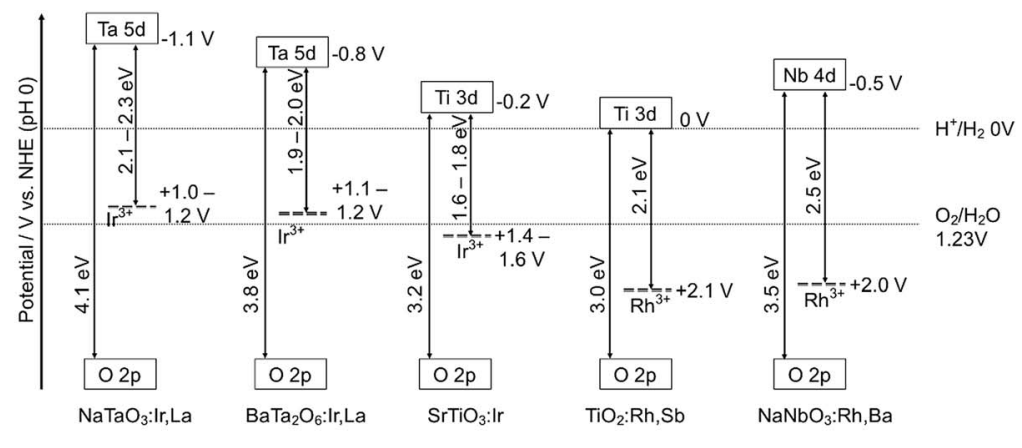

$\mathrm{H}_{2}$ evolution $\mathrm{O}_{2}$ evolution
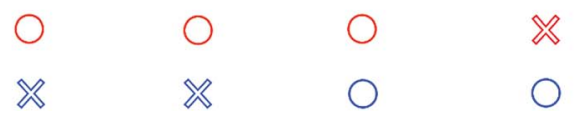

Fig. 4 The band structures of Rh- or Ir-doped metal oxide photocatalysts at $\mathrm{pH} 0$. 


\section{Z-schematic systems for photocatalytic water splitting employing Rh- and Ir- doped metal oxide materials}

The combination of $\mathrm{SrTiO}_{3}: \mathrm{Rh}$ and $\mathrm{BiVO}_{4}$ photocatalysts can be a benchmark of a Z-scheme photocatalyst system. The Z-schematic water splitting proceeds using $\mathrm{Fe}^{3+/ 2+}$ and $\left[\mathrm{Co}(\mathrm{bpy})_{3}\right]^{3+/ 2+}$ redox couples as ionic mediators (Fig. 1(a)) $)^{\mathbf{1 6 , 2 8 , 2 9}}$ and also via interparticle electron transfer between $\mathrm{SrTiO}_{3}: \mathrm{Rh}$ and $\mathrm{BiVO}_{4}$ particles with and without RGO (Fig. 1(b) and (c)). ${ }^{30,33,34}$ In general, water splitting via Zschematic interparticle electron transfer by contact between the particles of the $\mathrm{H}_{2}$ - and $\mathrm{O}_{2}$-evolving photocatalysts with and without $\mathrm{RGO}$ can be achieved (Fig. 1(b) and (c)) when the $\mathrm{H}_{2}$ - and $\mathrm{O}_{2}$-evolving photocatalysts satisfy the following two requirements; (i) $\mathrm{H}_{2}$ - and $\mathrm{O}_{2}$-evolving photocatalysts possess $\mathrm{p}$ - and n-type semiconductor properties, respectively, (ii) there is a certain electrode potential at which the cathodic photocurrent of the p-type semiconductor overlaps with the anodic photocurrent of the n-type semiconductor, being similar to water splitting using a photoelectrochemical cell working with no applied external bias as shown in Fig. $1(\mathrm{~d}) .^{31,32}$ Moreover, $\mathrm{H}_{2}$ - and $\mathrm{O}_{2}$-evolving photocatalysts must have contact with each other for interparticle electron transfer. In contrast to this, a Z-scheme system employing an ionic electron mediator could work regardless of the p- or n-type properties of the $\mathrm{H}_{2}$ - or $\mathrm{O}_{2}$-evolving photocatalysts, if the photocatalysts have potentials for the reduction or oxidation of redox couple ionic mediators and the adsorption abilities for the redox couples. The $\mathrm{SrTiO}_{3}: \mathrm{Rh}$ and $\mathrm{BiVO}_{4}$ photocatalysts satisfy these factors resulting in all of the Z-scheme systems showing activities for water splitting into $\mathrm{H}_{2}$ and $\mathrm{O}_{2}$ in stoichiometric amounts without any sacrificial reagents (Fig. 1(a)-(d)).

Various types of Z-scheme photocatalyst systems employing Ir- and Rh-doped photocatalysts for water splitting into $\mathrm{H}_{2}$ and $\mathrm{O}_{2}$ under visible light irradiation are shown in Table 2. Here, the absolute evaluation of the performance of photocatalyst systems for water splitting is how much $\mathrm{H}_{2}$ and $\mathrm{O}_{2}$ is obtained under certain experimental conditions. In this sense, the activities of the different $\mathrm{Z}$ scheme systems in Table 2 are comparable with each other, but not with those of Table 1 , because of the almost identical experimental conditions for the water splitting, even if the kinetics would be different among the systems.

For the construction of $\mathrm{Z}$-scheme systems, $\mathrm{BiVO}_{4}$ (an $\mathrm{O}_{2}$-evolving photocatalyst) was combined with $\mathrm{BaTa}_{2} \mathrm{O}_{6}: \mathrm{Ir}, \mathrm{La}$ and $\mathrm{NaTaO}_{3}: \mathrm{Ir}, \mathrm{La}\left(\mathrm{H}_{2}\right.$-evolving photocatalysts), while $\mathrm{SrTiO}_{3}: \mathrm{Rh}$ (an $\mathrm{H}_{2}$-evolving photocatalyst) was combined with $\mathrm{TiO}_{2}: \mathrm{Rh}, \mathrm{Sb}, \mathrm{NaNbO}_{3}: \mathrm{Rh}, \mathrm{Ba}$ and $\mathrm{SrTiO}_{3}: \mathrm{Ir}\left(\mathrm{O}_{2}\right.$-evolving photocatalysts $)$ as suggested by their $\mathrm{H}_{2}$ and $\mathrm{O}_{2}$ evolution abilities. In addition to the suspension system, the photoelectrochemical properties of photocatalyst powders immobilized on a conducting substrate as shown in Fig. 1(d) were examined using a Pt counter electrode without any sacrificial reagents to see the cathodic or anodic photocurrent and the onset potentials of semiconductor properties, not as a water splitting device, as shown in Fig. 5, in order to consider the potential overlap for Zschematic water splitting via interparticle electron transfer with and without RGO. It has been reported that $\mathrm{SrTiO}_{3}: \mathrm{Rh}^{36,40}$ and $\mathrm{BiVO}_{4}{ }^{32,41-44}$ function as a photocathode and photoanode, respectively. $\mathrm{NaTaO}_{3}: \mathrm{Ir}, \mathrm{La}$ showed only an anodic photocurrent. Although $\mathrm{BaTa}_{2} \mathrm{O}_{6}$ : $\mathrm{Ir}, \mathrm{La}$ and $\mathrm{SrTiO}_{3}$ :Ir showed cathodic and anodic photocurrents, the photocurrents were poor and the onset potentials shifted with the sweeping direction of the CV curves. This result implies that 


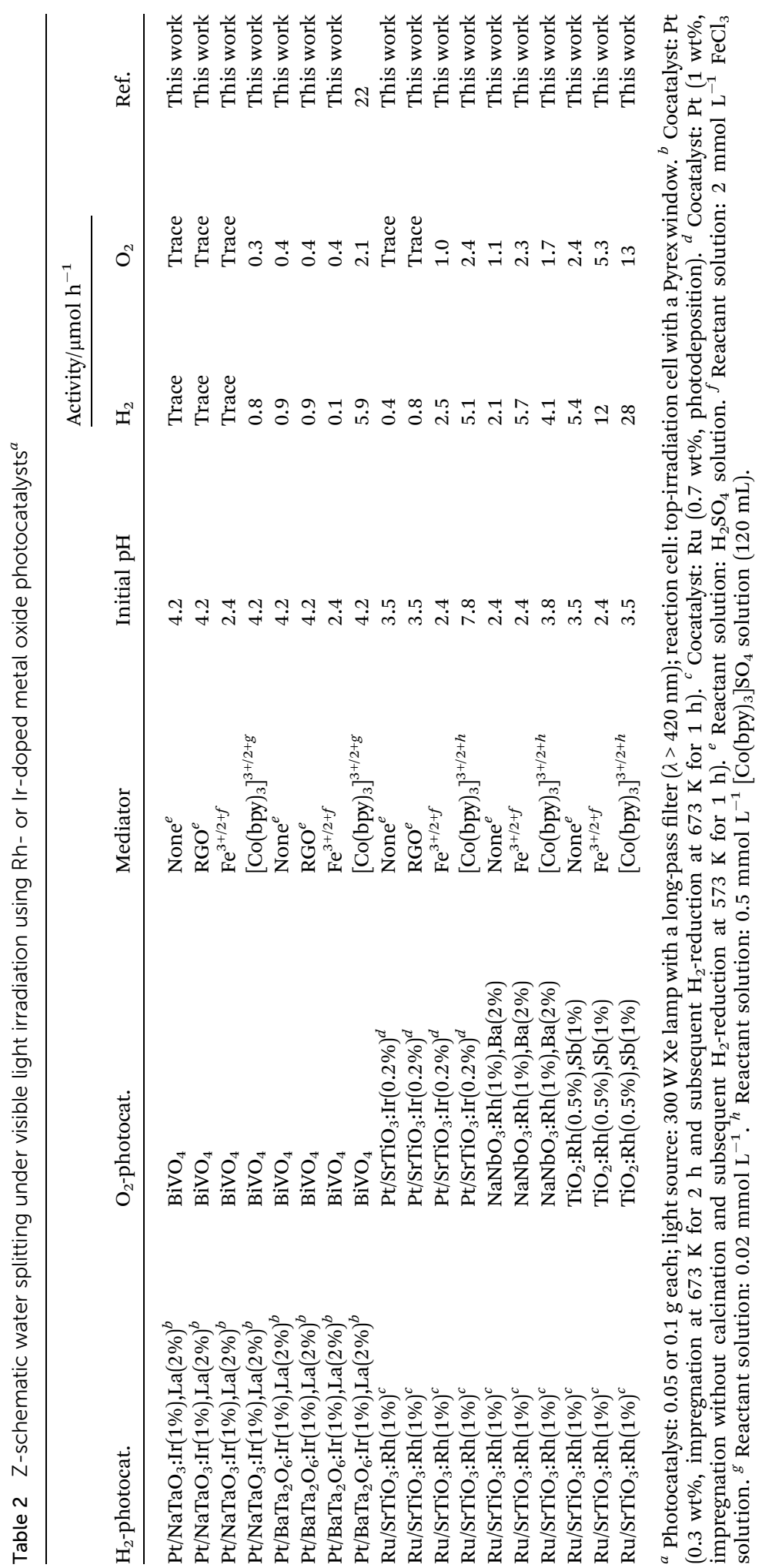




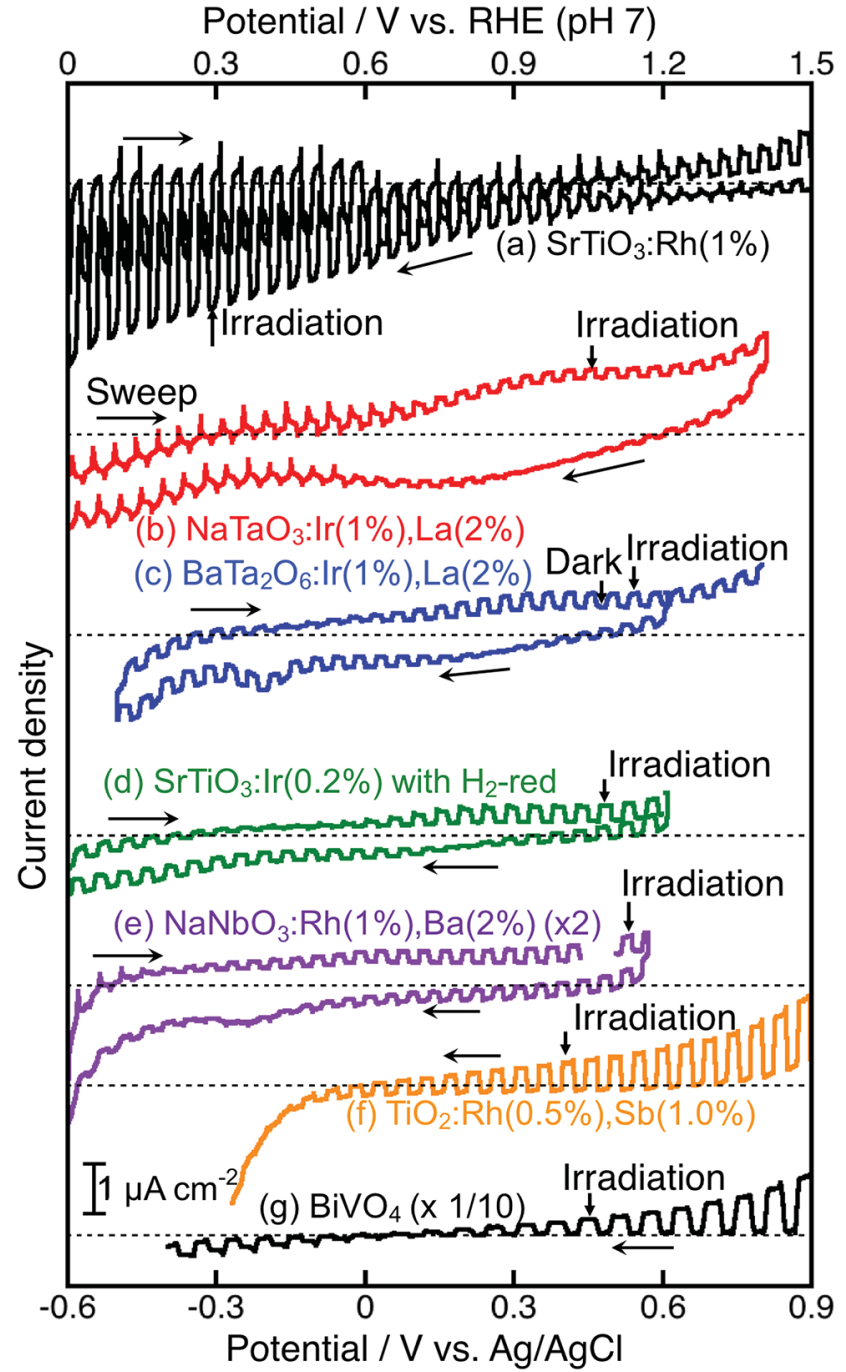

Fig. 5 Current vs. potential curves of (a) $\mathrm{SrTiO}_{3}: \mathrm{Rh}(1 \%)$, (b) $\mathrm{NaTaO}_{3}: \operatorname{Ir}(1 \%), \mathrm{La}(2 \%)$, (c) $\mathrm{BaTa}_{2} \mathrm{O}_{6}: \operatorname{Ir}(1 \%), \mathrm{La}(2 \%),(\mathrm{d}) \mathrm{SrTiO}_{3}: \operatorname{Ir}(0.2 \%)$ with $\mathrm{H}_{2}$ reduction, (e) $\mathrm{NaNbO}_{3}: \mathrm{Rh}(1 \%), \mathrm{Ba}(2 \%)$, (f) $\mathrm{TiO}_{2}: \mathrm{Rh}(0.5 \%), \mathrm{Sb}(1 \%)$, and (g) BiVO . Electrolyte: $0.1 \mathrm{~mol} \mathrm{~L}^{-1} \mathrm{~K}_{2} \mathrm{SO}_{4}$ aqueous solution ( $\mathrm{pH} 7$, phosphate buffer was added if necessary), light source: $300 \mathrm{~W}$ Xe lamp $(\lambda>420 \mathrm{~nm})$.

those photocurrents might not be due to $\mathrm{H}_{2}$ and $\mathrm{O}_{2}$ evolutions, but possibly due to redox reactions of the doped Ir species. In contrast, $\mathrm{TiO}_{2}: \mathrm{Rh}, \mathrm{Sb},{ }^{45}$ and $\mathrm{NaNbO}_{3}:-$ $\mathrm{Rh}, \mathrm{Ba}$ gave clear anodic photocurrents indicating an n-type semiconductor character. The onset potential of $\mathrm{NaNbO}_{3}: \mathrm{Rh}, \mathrm{Ba}$ was more negative than that of $\mathrm{TiO}_{2}: \mathrm{Rh}, \mathrm{Sb}$, whereas the anodic photocurrent of $\mathrm{NaNbO}_{3}: \mathrm{Rh}, \mathrm{Ba}$ was much smaller than that of $\mathrm{TiO}_{2}: \mathrm{Rh}, \mathrm{Sb}$. These anodic photocurrents overlapped with the cathodic photocurrent of $\mathrm{SrTiO}_{3}: \mathrm{Rh}$ at a certain electrode potential.

The Z-scheme systems were classified into three groups depending on the combination of $\mathrm{H}_{2}$ - and $\mathrm{O}_{2}$-evolving photocatalysts and an electron mediator; 
being active for only a $\left[\mathrm{Co}(\mathrm{bpy})_{3}\right]^{3+/ 2+}$ redox couple, active for $\left[\mathrm{Co}(\mathrm{bpy})_{3}\right]^{3+/ 2+}$ and $\mathrm{Fe}^{3+/ 2+}$ redox couple ionic mediators, active not only for $\left[\mathrm{Co}(\mathrm{bpy})_{3}\right]^{3+/ 2+}$ and $\mathrm{Fe}^{3+/ 2+}$ redox couples but also via interparticle electron transfer with and without RGO. $\mathrm{NaTaO}_{3}: \mathrm{Ir}, \mathrm{La}+\mathrm{BiVO}_{4}$ and $\mathrm{BaTa}_{2} \mathrm{O}_{6}: \mathrm{Ir}, \mathrm{La}+\mathrm{BiVO}_{4}$ were active when not $\mathrm{Fe}^{3+/ 2+}$ but a $\left[\mathrm{Co}(\mathrm{bpy})_{3}\right]^{3+/ 2+}$ redox couple was used. Although the $\mathrm{BaTa}_{2} \mathrm{O}_{6}: \mathrm{Ir}, \mathrm{La}+\mathrm{BiVO}_{4}$ showed activities via interparticle electron transfer at a $\mathrm{pH}$ of 4.2 with and without $\mathrm{RGO}$, the activities were smaller than that with the ionic electron mediator $\left[\mathrm{Co}(\mathrm{bpy})_{3}\right]^{3+/ 2+}$. $\mathrm{SrTiO}_{3}: \mathrm{Rh}+\mathrm{SrTiO}_{3}: \mathrm{Ir}$ was active when the $\left[\mathrm{Co}(\mathrm{bpy})_{3}\right]^{3+/ 2+}$ and $\mathrm{Fe}^{3+/}$ ${ }^{2+}$ redox couple ionic mediators were used, whereas it was not active via interparticle electron transfer with and without $\mathrm{RGO}$ at $\mathrm{pH}$ 3.5. $\mathrm{SrTiO}_{3}: \mathrm{Rh}+$ $\mathrm{NaNbO}_{3}: \mathrm{Rh}, \mathrm{Ba}$ and $\mathrm{SrTiO}_{3}: \mathrm{Rh}+\mathrm{TiO}_{2}: \mathrm{Rh}, \mathrm{Sb}$ were active for the $\left[\mathrm{Co}(\mathrm{bpy})_{3}\right]^{3+/ 2+}$ and $\mathrm{Fe}^{3+/ 2+}$ redox couples and via interparticle electron transfer without RGO. These Zscheme systems with RGO using $\mathrm{NaNbO}_{3}: \mathrm{Rh}, \mathrm{Ba}$ and $\mathrm{TiO}_{2}: \mathrm{Rh}, \mathrm{Sb}$ were not examined in detail, because the GOs were not suitably photoreduced on the $\mathrm{NaNbO}_{3}: \mathrm{Rh}, \mathrm{Ba}$ and $\mathrm{TiO}_{2}: \mathrm{Rh}, \mathrm{Sb}$ due to their poor reducing activities, as expected from their poor $\mathrm{H}_{2}$ evolution activities as shown in Table $1 . \mathrm{SrTiO}_{3}: \mathrm{Rh}+\mathrm{TiO}_{2}$ :$\mathrm{Rh}, \mathrm{Sb}$ showed the best performances among the Z-scheme systems in Table 2.

\section{Discussion}

$\mathrm{H}_{2}$ and $\mathrm{O}_{2}$ evolution abilities (shown in Table 1) can be considered based on the band structure, as shown in Fig. 4. Photogenerated holes in the $\operatorname{~Ir}^{3+}$ levels in $\mathrm{NaTaO}_{3}: \mathrm{Ir}$,La and $\mathrm{BaTa}_{2} \mathrm{O}_{6}: \mathrm{Ir}$,La have no potentials for water oxidation. In contrast, the $\mathrm{Ir}^{3+}$ level of $\mathrm{SrTiO}_{3}: \mathrm{Ir}$ possesses the water oxidation potential, though the driving force is not so large. Conduction bands consisting of Ta $5 \mathrm{~d}$ orbitals in $\mathrm{BaTa}_{2} \mathrm{O}_{6}: \mathrm{Ir}$,La and $\mathrm{NaTaO}_{3}: \mathrm{Ir}$,La possess thermodynamically enough potentials for water reduction to form $\mathrm{H}_{2}$. On the other hand, the photogenerated holes in the $\mathrm{Rh}^{3+}$ levels in $\mathrm{NaNbO}_{3}: \mathrm{Rh}, \mathrm{Ba}$ and $\mathrm{TiO}_{2}: \mathrm{Rh}, \mathrm{Sb}$ have enough potential for water oxidation to form $\mathrm{O}_{2}$. These energy levels were consistent with the $\mathrm{H}_{2}$ and $\mathrm{O}_{2}$ evolution abilities, as shown in Table 1. Of course, other kinetic factors of the active sites would exist for the $\mathrm{H}_{2}$ and $\mathrm{O}_{2}$ evolution abilities in addition to the energy levels of the thermodynamic factor.

Let us consider the reason why the Z-scheme systems shown in Table 2 are classified into three groups, based on the band structure and photoelectrochemical properties. Fig. 6 shows energy diagrams for the Z-schemes employing $\mathrm{Fe}^{3+/ 2+}$ and $\left[\mathrm{Co}(\mathrm{bpy})_{3}\right]^{3+/ 2+}$ redox couples at $\mathrm{pH} 2.4$ and 4.0, respectively. It is assumed that the band levels shift with $-0.059 \mathrm{~V} \mathrm{pH}^{-1}$ because those materials are metal oxides.

$\mathrm{NaTaO}_{3}: \mathrm{Ir}, \mathrm{La}+\mathrm{BiVO}_{4}$ and $\mathrm{BaTa}_{2} \mathrm{O}_{6}: \mathrm{Ir}, \mathrm{La}+\mathrm{BiVO}_{4}$ were active with a $\left[\mathrm{Co}(\mathrm{bpy})_{3}\right]^{3+/ 2+}$ redox couple at $\mathrm{pH} 4.2$, but not with $\mathrm{Fe}^{3+/ 2+}$ at $\mathrm{pH}$ 2.4. Photogenerated holes in the $\mathrm{Ir}^{3+}$ levels in $\mathrm{NaTaO}_{3}$ : Ir, La and $\mathrm{BaTa}_{2} \mathrm{O}_{6}$ : $\mathrm{Ir}$, La $\left(\right.$ an $\mathrm{H}_{2}{ }^{-}$ evolving photocatalyst) possess small driving forces for oxidation of $\mathrm{Fe}^{2+}$ (an electron mediator) at pH 2.4 as shown in Fig. 6(a), whereas they possess enough potential for oxidation of $\left[\mathrm{Co}(\mathrm{bpy})_{3}\right]^{2+}$ at $\mathrm{pH} 4.2$ as shown in Fig. 6(b). The activities from the interparticle electron transfer were very small or negligible because of poor photoresponse and poor overlaps of the potentials giving cathodic photocurrents of $\mathrm{NaTaO}_{3}: \mathrm{Ir}, \mathrm{La}$ and $\mathrm{BaTa}_{2} \mathrm{O}_{6}: \mathrm{Ir}$,La and an anodic photocurrent of $\mathrm{BiVO}_{4}$ as shown in Fig. 5, and also may be due to poor contact between $\mathrm{NaTaO}_{3}$ :Ir,La or $\mathrm{BaTa}_{2} \mathrm{O}_{6}$ :Ir, La (an $\mathrm{H}_{2}$-evolving photocatalyst) and $\mathrm{BiVO}_{4}$ (an $\mathrm{O}_{2}{ }^{-}$ 

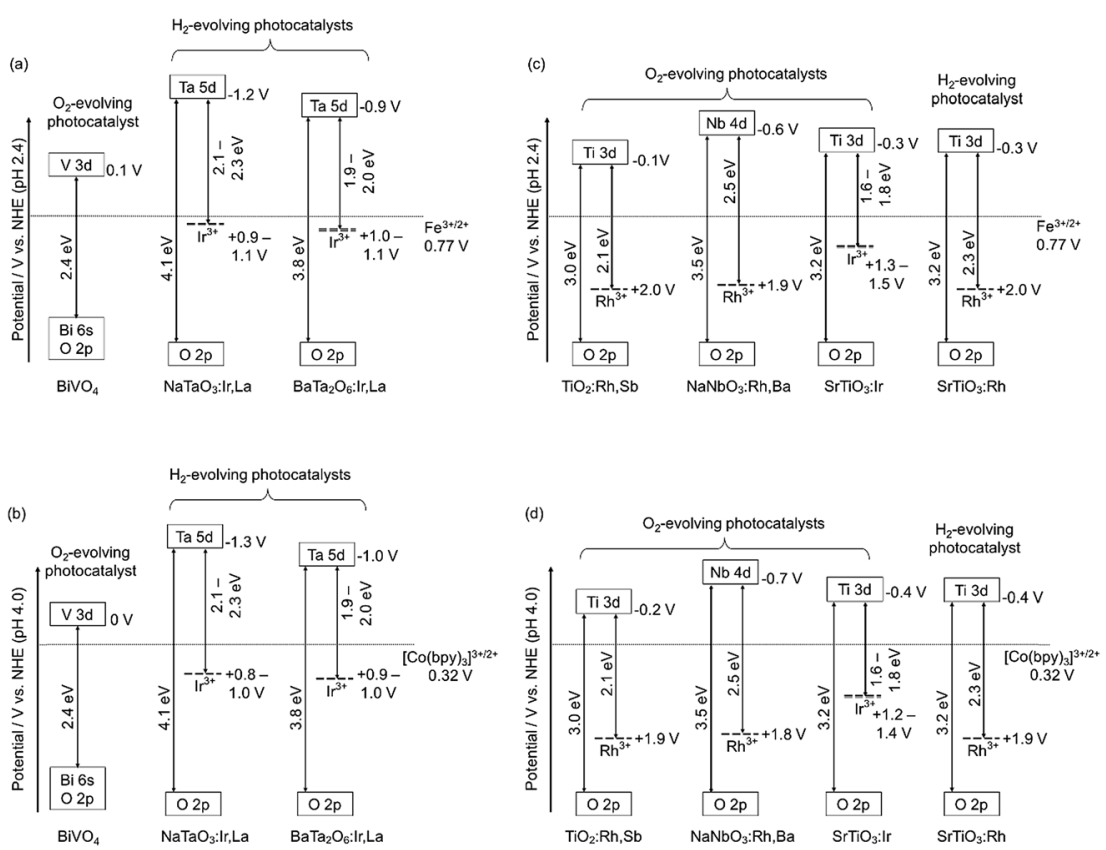

Fig. 6 The band structures of Rh- or Ir-doped metal oxide photocatalysts, and redox potentials of Fe and Co-complex ionic electron mediators at pH 2.4 and 4.0. (a) and (b) represent Z-scheme systems of Ir-doped metal oxides as $\mathrm{H}_{2}$-evolving photocatalysts combined with $\mathrm{BiVO}_{4}$. (c) and (d) represent Z-scheme systems of Rh-doped metal oxides and $\mathrm{SrTiO}_{3}:$ Ir as $\mathrm{O}_{2}$-evolving photocatalysts combined with $\mathrm{SrTiO}_{3}: \mathrm{Rh}$.

evolving photocatalyst) in the suspension at $\mathrm{pH}$ 4.2. In contrast to them, $\mathrm{SrTiO}_{3}: \mathrm{Rh}+\mathrm{SrTiO}_{3}: \mathrm{Ir}$ was active when the $\left[\mathrm{Co}(\mathrm{bpy})_{3}\right]^{3+/ 2+}$ and $\mathrm{Fe}^{3+/ 2+}$ redox couple ionic mediators were used, because the conduction band of $\mathrm{SrTiO}_{3}$ : $\operatorname{Ir}\left(\mathrm{an} \mathrm{O}_{2^{-}}\right.$ evolving photocatalyst) has enough potential for the reduction of $\mathrm{Fe}^{3+}$ and $\left[\mathrm{Co}(\mathrm{bpy})_{3}\right]^{3+}$ (Fig. 6(c) and (d)). However, because the anodic photocurrent of $\mathrm{SrTiO}_{3}:$ Ir hardly overlapped with the cathodic photocurrent of $\mathrm{SrTiO}_{3}: \mathrm{Rh}$, the activities by interparticle electron transfer with and without RGO were negligible. The conduction bands of $\mathrm{TiO}_{2}: \mathrm{Rh}, \mathrm{Sb}$ and $\mathrm{NaNbO}_{3}: \mathrm{Rh}, \mathrm{Ba}\left(\mathrm{O}_{2}\right.$-evolving photocatalysts) also possessed enough potential for the reduction of $\mathrm{Fe}^{3+}$ and $\left[\mathrm{Co}(\mathrm{bpy})_{3}\right]^{3+}$ as well as $\mathrm{SrTiO}_{3}: \mathrm{Ir}$ (Fig. 6(c) and (d)). Moreover, in these cases, the anodic photocurrents of the $\mathrm{TiO}_{2}: \mathrm{Rh}, \mathrm{Sb}$ and $\mathrm{NaNbO}_{3}: \mathrm{Rh}, \mathrm{Ba}$ photoelectrodes overlapped enough with the cathodic photocurrent of $\mathrm{SrTiO}_{3}: \mathrm{Rh}$. So, it is reasonable that $\mathrm{SrTiO}_{3}: \mathrm{Rh}+\mathrm{NaNbO}_{3}: \mathrm{Rh}, \mathrm{Ba}$ and $\mathrm{SrTiO}_{3}: \mathrm{Rh}+\mathrm{TiO}_{2}: \mathrm{Rh}, \mathrm{Sb}$ were active not only for the $\left[\mathrm{Co}(\mathrm{bpy})_{3}\right]^{3+/ 2+}$ and $\mathrm{Fe}^{3+/ 2+}$ redox couples but also via interparticle electron transfer with and without RGO. The activity of $\mathrm{SrTiO}_{3}: \mathrm{Rh}+$ $\mathrm{TiO}_{2}: \mathrm{Rh}, \mathrm{Sb}$ was higher than that of $\mathrm{SrTiO}_{3}: \mathrm{Rh}+\mathrm{NaNbO}_{3}: \mathrm{Rh}$,Ba for all of the types of $\mathrm{Z}$-scheme system. In the cases with the use of ionic electron mediators, it is probably due to the higher activity for $\mathrm{O}_{2}$ evolution and the narrower energy gaps of $\mathrm{TiO}_{2}: \mathrm{Rh}, \mathrm{Sb}$ than those of $\mathrm{NaNbO}_{3}: \mathrm{Rh}, \mathrm{Ba}$, as shown in Table 1 . The reason why $\mathrm{SrTiO}_{3}: \mathrm{Rh}+\mathrm{TiO}_{2}: \mathrm{Rh}, \mathrm{Sb}$ showed a higher activity than $\mathrm{SrTiO}_{3}: \mathrm{Rh}+\mathrm{NaNbO}_{3}: \mathrm{Rh}, \mathrm{Ba}$ via interparticle electron transfer is that $\mathrm{TiO}_{2}: \mathrm{Rh}, \mathrm{Sb}$ gave much larger anodic photocurrents than $\mathrm{NaNbO}_{3}: \mathrm{Rh}, \mathrm{Ba}$, as shown in Fig. 5 . 


\section{Conclusions}

We have successfully developed Z-scheme photocatalyst systems for water splitting under visible light irradiation employing Rh- and Ir-doped metal oxide photocatalysts with longer wavelength responses than conventional $\mathrm{SrTiO}_{3}: \mathrm{Rh}$ and $\mathrm{BiVO}_{4}$. The impurity levels of doped $\mathrm{Ir}^{3+}$ and $\mathrm{Rh}^{3+}$ that contributed to the visible light responses for the photocatalytic reactions were determined from diffuse reflectance spectra and supposing $+3.0 \mathrm{~V} v$ s. NHE of a valence band of the oxide photocatalyst materials. The impurity levels of $\mathrm{Ir}^{3+}$ in $\mathrm{NaTaO}_{3}: \mathrm{Ir}, \mathrm{La}$ and $\mathrm{BaTa}_{2} \mathrm{O}_{6}$ :Ir,La have sufficient potentials for the oxidation of the electron mediator $\left[\mathrm{Co}(\mathrm{bpy})_{3}\right]^{2+}$, but insufficient potentials for water oxidation to form $\mathrm{O}_{2}$ and oxidation of the electron mediator $\mathrm{Fe}^{2+}$. The conduction bands of the $\mathrm{NaTaO}_{3}$ :Ir, La and $\mathrm{BaTa}_{2} \mathrm{O}_{6}$ :Ir, La have enough potential for water reduction to form $\mathrm{H}_{2}$. Therefore, the $\mathrm{NaTaO}_{3}: \mathrm{Ir}, \mathrm{La}$ and $\mathrm{BaTa}_{2} \mathrm{O}_{6}: \mathrm{Ir}$,La could be used as $\mathrm{H}_{2}$-evolving photocatalysts only when a $\left[\mathrm{Co}(\mathrm{bpy})_{3}\right]^{3+/ 2+}$ redox couple was used. The impurity levels of $\mathrm{Ir}^{3+}$ in $\mathrm{SrTiO}_{3}: \mathrm{Ir}$ and $\mathrm{Rh}^{3+}$ in $\mathrm{TiO}_{2}: \mathrm{Rh}, \mathrm{Sb}$ and $\mathrm{NaNbO}_{3}: \mathrm{Rh}, \mathrm{Ba}$ have potentials for water oxidation and their conduction bands possess the potentials for reduction of the electron mediators $\mathrm{Fe}^{3+}$ and $\left[\mathrm{Co}(\mathrm{bpy})_{3}\right]^{3+}$. This property means that $\mathrm{SrTiO}_{3}: \mathrm{Ir}, \mathrm{TiO}_{2}: \mathrm{Rh}, \mathrm{Sb}$ and $\mathrm{NaNbO}_{3}: \mathrm{Rh}, \mathrm{Ba}$ could be employed as $\mathrm{O}_{2}$-evolving photocatalysts for the construction of Z-scheme systems employing ionic electron mediators. Moreover, photoelectrochemical measurements using photocatalyst powders immobilized on conducting substrate revealed that the n-type characters and relatively negative onset potentials of the $\mathrm{TiO}_{2}: \mathrm{Rh}, \mathrm{Sb}$ and $\mathrm{NaNbO}_{3}: \mathrm{Rh}, \mathrm{Ba}$ photoanodes enabled the Z-scheme systems to work by interparticle electron transfer. Although the efficiencies of the present Z-scheme systems are low at the present stage, these will be improved by interfacial controls from a kinetic point of view in basic research. These results and discussion will contribute to the design of a highly active photocatalyst system for water splitting into $\mathrm{H}_{2}$ and $\mathrm{O}_{2}$, aiming for the demonstration of actual solar water splitting using a suitable reactor.

\section{Conflicts of interest}

There are no conflicts to declare.

\section{Acknowledgements}

This work was supported by JSPS KAKENHI Grant Numbers $17 \mathrm{H} 06440$ and 17H06433 in Scientific Research on Innovative Areas "Innovations for LightEnergy Conversion ( ${ }^{4}$ LEC)".

\section{References}

1 A. Kudo, H. Kato and I. Tsuji, Chem. Lett., 2004, 33, 1534.

2 A. Kudo and Y. Miseki, Chem. Soc. Rev., 2009, 38, 253.

3 F. E. Osterloh, Chem. Mater., 2008, 20, 35.

4 Y. Inoue, Energy Environ. Sci., 2009, 2, 364.

5 R. Abe, J. Photochem. Photobiol., C, 2010, 11, 179.

6 T. Hisatomi, J. Kubota and K. Domen, Chem. Soc. Rev., 2014, 43, 7520. 
7 K. Maeda and K. Domen, Bull. Chem. Soc. Jpn., 2016, 89, 627.

8 B. A. Pinaud, J. D. Benck, L. C. Seitz, A. J. Forman, Z. Chen, T. G. Deutsch, B. D. James, K. N. Baum, G. N. Baum, S. Ardo, H. Wang, E. Miller and T. F. Jaramillo, Energy Environ. Sci., 2013, 6, 1983.

9 D. M. Fabian, S. Hu, N. Singh, F. A. Houle, T. Hisatomi, K. Domen, F. E. Osterloh and S. Ardo, Energy Environ. Sci., 2015, 8, 2825.

10 T. Yamada and K. Domen, Chem. Eng., 2018, 2, 36.

11 A. Kudo, in "Photocatalysis", Contemporary Catalysis; Science, Technology and Applications, ed. P. Kamer, D. Vogt and J. Thybaut, Royal Society of Chemistry, Cambridge, 2017, ch. 3.7, pp. 326-343.

12 A. J. Bard, J. Photochem., 1979, 10, 59.

13 A. Kudo, MRS Bull., 2011, 36, 32.

14 K. Maeda, ACS Catal., 2013, 3, 1486.

15 Y. Wang, H. Suzuki, J. Xie, O. Tomita, D. J. Martin, M. Higashi, D. Kong, R. Abe and J. Tang, Chem. Rev., 2018, 118, 5201.

16 H. Kato, M. Hori, R. Konta, Y. Shimodaira and A. Kudo, Chem. Lett., 2004, 33, 1348.

17 Q. Wang, T. Hisatomi, Q. Jia, H. Tokudome, M. Zhong, C. Wang, Z. Pan, T. Takata, M. Nakabayashi, N. Shibata, Y. Li, I. D. Sharp, A. Kudo, T. Yamada and K. Domen, Nat. Mater., 2016, 15, 611.

18 Q. Wang, T. Hisatomi, Y. Suzuki, Z. Pan, J. Seo, M. Katayama, T. Minegishi, H. Nishiyama, T. Takata, K. Seki, A. Kudo, T. Yamada and K. Domen, J. Am. Chem. Soc., 2017, 139, 1675.

19 Q. Wang, T. Hisatomi, M. Katayama, T. Takata, T. Minegishi, A. Kudo, T. Yamada and K. Domen, Faraday Discuss., 2017, 197, 491.

20 R. Konta, T. Ishii, H. Kato and A. Kudo, J. Phys. Chem. B, 2004, 108, 8992.

21 R. Niishiro, S. Tanaka and A. Kudo, Appl. Catal., B, 2014, 150, 187.

22 S. Suzuki, H. Matsumoto, A. Iwase and A. Kudo, Chem. Commun., 2018, 54, 10606.

23 A. Iwase and A. Kudo, Chem. Commun., 2017, 53, 6156.

24 A. Iwase, K. Saito and A. Kudo, Bull. Chem. Soc. Jpn., 2009, 82, 514.

25 R. Niishiro, R. Konta, H. Kato, W. J. Chun, K. Asakura and A. Kudo, J. Phys. Chem. C, 2007, 111, 17420.

26 A. Kudo, K. Omori and H. Kato, J. Am. Chem. Soc., 1999, 121, 11459.

27 A. Iwase, H. Kato and A. Kudo, J. Sol. Energy Eng., 2010, 132, 21106.

28 Y. Sasaki, A. Iwase, H. Kato and A. Kudo, J. Catal., 2008, 259, 133.

29 Y. Sasaki, H. Kato and A. Kudo, J. Am. Chem. Soc., 2013, 135, 5441.

30 A. Iwase, Y. H. Ng, Y. Ishiguro, A. Kudo and R. Amal, J. Am. Chem. Soc., 2011, 133, 11054.

31 K. Iwashina, A. Iwase, Y. H. Ng, R. Amal and A. Kudo, J. Am. Chem. Soc., 2015, 137, 604.

32 A. Iwase, S. Yoshino, T. Takayama, Y. H. Ng, R. Amal and A. Kudo, J. Am. Chem. Soc., 2016, 138, 10260.

33 Y. Sasaki, H. Nemoto, K. Saito and A. Kudo, J. Phys. Chem. C, 2009, 113, 17536.

34 Q. Jia, A. Iwase and A. Kudo, Chem. Sci., 2014, 5, 1513.

35 W. S. Hummers and R. E. Offeman, J. Am. Chem. Soc., 1958, 80, 1339.

36 K. Iwashina and A. Kudo, J. Am. Chem. Soc., 2011, 133, 13272.

37 S. Kawasaki, K. Akagi, K. Nakatsuji, S. Yamamoto, I. Matsuda, Y. Harada, J. Yoshinobu, F. Komori, R. Takahashi, M. Lippmaa, C. Sakai, H. Niwa, M. Oshima, K. Iwashina and A. Kudo, J. Phys. Chem. C, 2012, 116, 24445. 
38 S. Kawasaki, R. Takahashi, K. Akagi, J. Yoshinobu, F. Komori, K. Horiba, H. Kumigashira, K. Iwashina, A. Kudo and M. Lippmaa, J. Phys. Chem. C, 2014, 118, 20222.

39 D. E. Scaife, Sol. Energy, 1980, 25, 41.

40 S. Kawasaki, K. Nakatsuji, J. Yoshinobu, F. Komori, R. Takahashi, M. Lippmaa, K. Mase and A. Kudo, Appl. Phys. Lett., 2012, 101, 033910.

41 K. Sayama, A. Nomura, Z. Zou, R. Abe, Y. Abe and H. Arakawa, Chem. Commun., 2003, 2908.

42 K. Sayama, A. Nomura, T. Arai, T. Sugita, R. Abe, M. Yanagida, T. Oi, Y. Iwasaki, Y. Abe and H. Sugihara, J. Phys. Chem. B, 2006, 110, 2908; F. F. Adbi, L. Han, A. H. M. Smets, M. Zeman, B. Dam and R. van de Krol, Nat. Commun., 2013, 4, 2195.

43 Y. Park, K. J. McDonald and K.-S. Choi, Chem. Soc. Rev., 2013, 42, 2321.

44 Q. Jia, K. Iwashina and A. Kudo, Proc. Natl. Acad. Sci. U. S. A., 2012, 109, 11564.

45 M. Yamaguchi, R. Niishiro, Q. Jia, Y. Kuang, K. Kitamura, A. Iwase, T. Minegishi, T. Yamada, K. Domen and A. Kudo, to be submitted. 